\title{
Konsumsi Natrium, Lemak Jenuh dan Serat Berhubungan dengan Kejadian Penyakit Jantung Koroner di Rumah Sakit dr. Zainoel Abidin, Banda Aceh
}

\author{
Wiqayatun Khazanah', Nunung Sri Mulyani', Ramadhaniah ${ }^{2}$, Cut Siti Novia Rahma ${ }^{1}$ \\ Jurusan Gizi, Politeknik Kesehatan Kemenkes Aceh, Indonesia ${ }^{1}$ \\ Universitas Muhammadiyah Aceh, Aceh, Indonesia ${ }^{2}$ \\ e-mail: nunungmulyani76@gmail.com
}

\begin{abstract}
Coronary heart disease is a condition that occurs due to the buildup of plaque in the heart arteries resulting in a disturbed blood supply to the heart which can cause a heart attack. The prevalence of CHD especially in the Aceh region ranges from $0.7 \%$. The causes of CHD are age, sex, genetics, smoking, hypertension, diabetes, stress, diet. The study was conducted in July 2018 at the RSUZA outpatient clinic in Banda Aceh. The research is descriptive analytical with cross sectional design with a sample of 178 people. Data collected consisted of primary and secondary which were tested by Chi-square statistics. Samples that have CHD are mostly dominated by male sex, and consume excess sodium, samples that do not have CHD offspring do not experience CHD and those with a history of hypertension experience CHD. There is a significant relationship between sodium consumption, saturated fat consumption and fiber consumption in the incidence of CHD in hospital dr Zainoel Abidin Banda Aceh ( $p$-value $\leq 0.01)$.
\end{abstract}

Keywords : CHD, fiber, saturated fat, sodium consumption.

\section{Pendahuluan}

Data WHO (2010), menunjukkan bahwa penyakit kardiovaskular merupakan penyebab kematian nomor satu secara global, yaitu sebagai penyebab $31 \%$ kematian. Pada tahun 2012 sekitar 17.5 juta orang di dunia meninggal dunia karena penyakit kardiovakular ini, yang terdiri dari $42 \%$ kematian karena penyakit jantung koroner, dan 38\% karena stroke. Di Indonesia, prevalensi penyakit jantung koroner berdasarkan diagnosis dokter dan gejala sekitar 1,5\%, gagal jantung $0,3 \%$, sedangkan prevalensi stroke berdasarkan diagnosis tenaga kesehatan dan gejala sebesar $1,2 \%$. Prevalensi penyakit jantung korener di Indonesia penyakit jantung dan pembuluh darah ini terus meningkatkan dan akan memberikan beban kesakitan, kecatatan dan beban sosial ekonomi bagi keluarga penderita, masyarakat dan Negara.

Prevalensi penyakit jantung koroner di Indonesia tahun 2013 berdasarkan diagnosis dokter gejala sebesar $1.5 \%$. Sementara itu prevalensi penyakit gagal jantung di Indonesia tahun 2013 berdasarkan diagnosis dokter sebesar $0.13 \%$. Prevalensi penyakit jantung koroner di Aceh sebesar 0.7\%. Pada tahun 2017 rata-rata jumlah pasien jantung coroner rawat jalan di RSUZA Banda Aceh sjumlah 840 orang perbulan (Rumah Sakit Umum Zainoel Abidin, 2017).
Penyakit jantung adalah penyebab utama kematian di seluruh dunia termasuk Indonesia. Perubahan gaya hidup seperti pola makan yang menjurus ke sajian siap santap yang tidak sehat dan tidak seimbang karena mengandung kalori, lemak, protein, dan garam tinggi tapi rendah serat pangan disinyalir menjadi faktor risiko meningkatnya prevalensi penyakit jantung (Zuraida, 2015).

Menurut American Heart Association (2010) (American Heart Association (AHA), 2010), yang menjadi faktor risiko penyakit jantung adalah faktor genetik, gaya hidup, status kesehatan, dan status sosial ekonomi. Faktor risiko yang termasuk faktor genetik (bawaan) adalah pertambahan usia, jenis kelamin pria, ras, dan riwayat keluarga sedangkan faktor risiko yang termasuk gaya hidup adalah diet tinggi lemak dan kurang serat, merokok, aktifitas fisik yang kurang, stres, dan konsumsi alkohol yang berlebihan, serta yang termasuk status kesehatan adalah diabetes mellitus, disipidemia, dan hipertensi.

Pola makan adalah salah satu cara atau usaha dalam pengaturan jumlah dan jenis makanan dengan informasi gambaran dengan meliputi mempertahankan kesehatan, status nutrisi, mencegah atau membantukesembuhan penyakit. Dan menurut seorang ahli mengatakan bahwa pola makan didefinisikan sebagai karakterisktik dari kegiatan yang setiap orang makan dalam memenuhi kebutuhan makanan. 
Asupan zat gizi mikro sepertinatrium yang berpengaruh terhadapkejadian tekanan darah tinggi atauhipertensi yang meningkatkan risikogangguan jantung, asupan zat gizi mikrolainnya yaitu vitamin sebagaiantioksidan. Selain mengkonsumsi asupan zatgizi makro seperti karbohidrat, lemak,protein, serta kurangnya asupan seratpada penyakit jantung ini dipengaruhijuga oleh asupan zat gizi mikro sepertinatrium dan vitamin. Konsumsi natriumyang berlebihan akan membahayakankesehatan. Konsumsi yang setaradengan 3 gram per $\mathrm{kg}$ berat badan dapatmengakibatkan kematian. Kelebihan berpengaruh langsung terhadap tekanan darah. Tekanan darah yang tinggi meningkatkan risiko gangguan jantung.Bagi para penderita hipertensi,sebaiknya menghindari penggunaangaram meja yang terlalu banyak ataumakanan-makanan yang tinggikandungan garam. Risiko biasanyasangat berat yakni terkena stroke. Halyang sama berlaku pada penderitakegemukan. Para penderita penyakitkelelahan yang disebut CFS (chronic fatigue syndrome) yang biasanyaditandai oleh tekanan darah rendah dianjurkan mengkonsumsi makanan yang memiliki kandungan garam yang cukup tinggi (Rahajoe, 2007).

Penyebab terjadinya penyakit jantung selain dari pola konsumsikarbohidrat, makanan tinggi lemak dan kolesterol, kurangnya asupan serat juga berpengaruh terhadap terjadinya penyakit jantung khususnya PJK. Serat juga dapat membantu menurunkan absorpsi lemak dan kolesterol darah. Penelitian menunjukkan bahwa diet serat berasal dari konsumsi makanan tinggi kacang polong, termasuk kacang merah, mampu menurunkan kadar kolesterol darah hingga $10 \%$ pada penderita hiperkolesterolemia, orang-orang yang mempunyai kadar kolesterol darah berlebihan (Nikmah, 2014).

Berdasarkan penelitian Tuminah (2009) (Tuminah, 2009), menyebutkan bahwa pola makan seperti konsumsi makanan yang tinggi lemak total atau lemak jenuh, kolesterol, serta kurangnya konsumsi karbohidrat merupakan faktor yang mempengaruhi kadar HDL dan merupakan faktor risiko PJK. Menurut Yusuf dkk (2013) (Yusuf, Yusnindar and Nisma, 2013), menyatakan bahwa konsumsi lemak terutama asam lemak jenuh, akan berpengaruh terhadap kadar Low Density
Lipoprotein (LDL) yang menyebabkan darah mudah menggumpal, selain itu asam lemak jenuh mampu merusak dinding pembuluh darah arteri sehingga menyebabkan penyempitan. Studi epidemiologi yang dilakukan Hardinsyah (2011) (Hardinsyah, 2011), membuktikan bahwa terdapat hubungan positif yang bermakna antara konsumsi lemak, asam lemak jenuh menyebabkan hiperkolesterol yang merupakan faktor risiko dari PJK (Sobari, 2014).

\section{Metode}

Penelitian ini bersifat deskriptif analitik dengan desain cross sectional untuk melihat hubungan pola makan dengan kejadian jantung koroner di Rumah Sakit Umum Daerah dr. Zainoel Abidin Banda Aceh.Penelitian ini dilaksanakan padabulan Juli 2018 di Rumah Sakit Umum Daerah dr.Zainoel Abidin Banda Aceh. Populasi yang digunakan dalam penelitian ini adalah seluruh pasien rawat jalan penyakit jantung koroner di Rumah Sakit Umum dr. Zainoel Abidin Banda Aceh.

\subsection{Metode Pengumpulan Data}

Sampel dalam penelitian ini di tentukan denganmetode purposive sampling yaitu sampel yang memenuhi kriteria yaitu : sampel berusia 40-70 tahun, dapat berkomunikasi, bersedia menjadi sampel, tidak membedakan jenis kelamin yang berjumlah 89 orang PJK dan 89 orang non PJK. Data primer meliputi konsumsi natrium, lemak jenuh, serat dan konsumsi gula dengan mewawancarai pasien dengan menggunakan alat bantu kuesioner SQ-FFQ dengan kategori : Sering bila konsumsi 3-4x per hari dan Jarang bila konsumsi 1-3x per bulan.

\subsection{Metode Analisis Data}

Analisis dan pengolahan data menggunakan uji Chi-Square.

\section{Hasil dan Pembahasan \\ 3.1 Konsumsi Natrium Dengan Kejadian Penyakit Jantung Koroner}

Berdasarkan Tabel 1dapat dilihat bahwa dari 112orang yang sering konsumsi makanan natrium sebagian besar memiliki riwayat jantung koroner yaitu berjumlah 65orang (58,0\%),sedangkan dari 66orang yang jarang konsumsi makanan natrium tidak memiliki riwayat jantung koroner sebanyak 42orang $(63,6 \%)$. Setelah dilakukan uji statistik dengan 
menggunakan chi-square test ada hubungan yang bermakna antara konsumsi natrium dengan kejadian penyakit jantung koroner.

Tabel 1. Hubungan Konsumsi Natrium Dengan Pasien Jantung Koroner di Ruang Rawat Jalan RSUD Zainoel Abidin Banda Aceh Tahun 2018

\begin{tabular}{|c|c|c|c|c|c|c|c|}
\hline \multirow{3}{*}{$\begin{array}{l}\text { Konsu } \\
\text { msi } \\
\text { Natriu } \\
\text { m }\end{array}$} & \multicolumn{4}{|c|}{$\begin{array}{c}\text { Kejadian Jantung } \\
\text { Koroner }\end{array}$} & \multirow{2}{*}{\multicolumn{2}{|c|}{ Jumlah }} & \multirow{3}{*}{$p$} \\
\hline & \multicolumn{2}{|c|}{ PJK } & \multicolumn{2}{|c|}{$\begin{array}{l}\text { Non } \\
\text { PJK }\end{array}$} & & & \\
\hline & $\mathbf{n}$ & $\%$ & n & $\%$ & n & $\%$ & \\
\hline Sering & 65 & $\begin{array}{l}58, \\
0\end{array}$ & 47 & $\begin{array}{l}42, \\
0\end{array}$ & 12 & $\begin{array}{l}10 \\
0\end{array}$ & 0,00 \\
\hline Jarang & 24 & $\begin{array}{l}36 \\
4\end{array}$ & 42 & $\begin{array}{l}63, \\
6\end{array}$ & 66 & $\begin{array}{l}10 \\
0\end{array}$ & 8 \\
\hline
\end{tabular}

Natrium merupakan pemicu timbulnya penyakit tekanan darah tinggi yang merupakan risiko untuk penyakit jantung koroner. Konsumsi natrium termasuk faktor risiko penyakit jantung, dapat dikatakan pula orang yang sering konsumsi natrium mempunyai risiko 1,17 kali terkena penyakit jantung dibandingkan dengan orang yang jarang mengkonsumsi makanan-makanan natrium (Zuraida, 2015).

Pola makan yang mengandung natrium tinggi ini dapat membawa konsekuensi terhadap perubahan status gizi menuju gizi lebih atau berat badan lebih dan obesitas yang dapat memicu berkembangnya penyakit degeneratif seperti penyakit jantung dan pembuluh darah, khususnya PJK. Hasil penelitian ini sejalan dengan penelitian yang dilakukan yang menyebutkan terdapat hubungan antara konsumsi natrium dengan kejadian PJK.

\subsection{Konsumsi Lemak Dengan Kejadian Penyakit Jantung Koroner}

Berdasarkan Tabel 2 dapat dilihat bahwa dari 109 orang yang sering konsumsi lemak jenuh sebagian besar memiliki riwayat jantung koroner yaitu berjumlah 62orang (56,9\%),sedangkan dari 69orang yang jarang konsumsi lemak tidak memiliki riwayat jantung koroner sebanyak 42 orang $(60,9 \%)$. Setelah dilakukan uji statistik dengan menggunakan chi-square test ada hubungan yang bermakna antara konsumsi lemak dengan kejadian penyakit jantung koroner.

PJK disebabkan oleh lapisan lemak atau kolesterol di dinding nadi yang menyumbat pembuluh darah koroner. Akibatnya dari penyumbatan oleh lapisan lemak dan kolesterol ini adalah terganggunya proses suplai darah ke jantung. Ketika darah tersumbat akibat lapisan lemak maka inilah yang disebut serangan jantung. Menurut National Heart Lung and Blood Institute, penyakit jantung koroner disebut juga penyakit arteri koroner, yaitu suatu kondisi dimana terbentuknya plak pada bagian dalam arteri koronaria. Arteri ini menyuplai darah yang kaya akan oksigen untuk otot jantung.

Tabel 2. Hubungan Konsumsi Lemak Dengan Pasien Jantung Koroner di Ruang Rawat Jalan RSUD Zainoel Abidin Banda Aceh Tahun 2018

\begin{tabular}{|c|c|c|c|c|c|c|c|}
\hline \multirow{3}{*}{$\begin{array}{c}\text { Kons } \\
\text { umsi } \\
\text { Lema } \\
\text { k }\end{array}$} & \multicolumn{4}{|c|}{$\begin{array}{l}\text { Kejadian Jantung } \\
\text { Koroner }\end{array}$} & \multirow{2}{*}{\multicolumn{2}{|c|}{ Jumlah }} & \multirow{3}{*}{$p$} \\
\hline & \multicolumn{2}{|c|}{ PJK } & \multicolumn{2}{|c|}{ Non PJK } & & & \\
\hline & $\mathbf{n}$ & $\%$ & $\mathbf{n}$ & $\%$ & $\mathbf{n}$ & $\%$ & \\
\hline Serin & & 56 & & & & & \\
\hline $\mathrm{g}$ & 62 & 9 & 27 & 39,1 & 109 & 100 & 0,03 \\
\hline $\begin{array}{c}\text { Jaran } \\
\mathrm{g}\end{array}$ & 47 & $\begin{array}{c}43 \\
1 \\
\end{array}$ & 42 & 60,9 & 69 & 100 & 1 \\
\hline
\end{tabular}

Asupan lemak yang berlebihan dapat membawa dampak buruk bagi kesehatan, karena dapat meningkatkan kadar lemak yang ada di dalam darah sehingga dapat menyebabkan penyakit jantung koroner. Kadar lemak yang berlebihan mengakibatkan terjadinya penimbunan lemak di sekitar pembuluh darah jantung, sehingga terjadi penyumbatan dan sel darah merah yang membawa oksigen untuk jantung menjadi berkurang. Hasil penelitian ini sejalan dengan penelitian yang dilakukan yang menyebutkan terdapat hubungan konsumsi makanan tinggi lemak jenuh dengan kejadian penyakit jantung koroner.

\subsection{Konsumsi Serat DenganKejadian Penyakit Jantung Koroner}

Berdasarkan Tabel 3dapat dilihat bahwa dari 102 orang yang sering konsumsi serat 
sebagian besar tidak memiliki riwayat jantung koroner yaitu berjumlah 54orang (71,1\%),sedangkan dari 76orang yang jarang konsumsi serat memiliki riwayat jantung koroner sebanyak 67 orang $(65,7 \%)$. Setelah dilakukan uji statistik dengan menggunakan chi-square test ada hubungan yang bermakna antara konsumsi serat dengan kejadian penyakit jantung koroner.

Tabel 3. Hubungan Konsumsi Serat Dengan Pasien Jantung Koroner di Ruang Rawat Jalan RSUD Zainoel Abidin Banda Aceh Tahun 2018.

\begin{tabular}{|c|c|c|c|c|c|c|c|}
\hline \multirow{3}{*}{$\begin{array}{c}\text { Konsu } \\
\text { msi } \\
\text { Serat }\end{array}$} & \multicolumn{4}{|c|}{$\begin{array}{c}\text { Kejadian Jantung } \\
\text { Koroner }\end{array}$} & \multirow{2}{*}{\multicolumn{2}{|c|}{ Jumlah }} & \multirow[t]{2}{*}{$p$} \\
\hline & \multicolumn{2}{|c|}{ PJK } & \multicolumn{2}{|c|}{ Non PJK } & & & \\
\hline & n & $\%$ & $\mathrm{n}$ & $\%$ & $\mathbf{n}$ & $\%$ & $\mathrm{p}$ \\
\hline & 2 & 28 & & & & 10 & \\
\hline Sering & 2 & 9 & 54 & 71,1 & 102 & 0 & 000 \\
\hline Jarang & $\begin{array}{l}6 \\
7\end{array}$ & $\begin{array}{c}65 \\
7\end{array}$ & 35 & 34,3 & 76 & $\begin{array}{c}10 \\
0\end{array}$ & \\
\hline
\end{tabular}

Serat merupakan faktor protektif dalam mencegah terjadinya PJK melalui perananya dalam mencegah penggumpalan darah, kegemukan dan aterosklerosis. Peneliti lain masih beranggapan bahwa mengkonsumsi makanan berserat tinggi merupakan kebiasaan dari gaya hidup dan pola makan sehat yang berperan pada menurunkan risiko PJK (Nikmah, 2014).

Makanan yang sebaiknya di konsumsi oleh penderita jantung koroner adalah makanan yang mengandung sayuran dan buah-buahan. Hal ini dapat disebabkan kedua jenis makanan ini banyak mengandung serat dan zat antioksidan dalam jumlah yang banyak (Alifiyanti, Iskari and Sri, 2016). Hasil penelitian ini sejalan dengan penelitian Alifiyanti, M. 2016 yang menyatakan bahwa konsumsi serat dikaitkan dengan tingkat penurunan penyakit jantung koroner. Sehingga dapat disimpulkan bahwa ada hubungan yang signifikan antara konsumsi serat dengan jantung koroner.

\section{Simpulan dan Saran}

\subsection{Simpulan}

Konsumsi natrium, lemak jenuh dan serat memiliki hubungan yang bermakna dengan kejadian penyakit jantung koroner pada pasien rawat jalan di poli penyakit dalam RSUZA Banda Aceh.

\subsection{Saran}

Rumah Sakit diharapkan meningkatkan kerjasama antara dokter dan ahli gizi untuk meningkatkan pengetahuan tentang pola makan melalui penyuluhan maupun konseling gizi untuk pasien jantung koroner dalam pengaturan makan serta merujuk pasien jantung koroner ke Poliklinik Gizi.

\section{Daftar Pustaka}

Alifiyanti, M., Iskari, N. and Sri, L. (2016) 'Relation between food consumption pattern of risk, fruit and vegetable consumption and heart disease events age of 45-59 years in sulawesi island (Data Analysis Of Riskesdas 2007)'.

American Heart Association (AHA) (2010) 'Adult Basic Life Support: Guidelines for $C P R$ and Emergency Cardiovascular Care'. Available at: http://circ.ahajournals.org/content/122/18_ suppl_3/S685.

Hardinsyah (2011) Kualitas Pelayanan Publik. Yogyakarta: Gava Media.

Nikmah, L. (2014) Perbedaan Intake Serat, Natrium, dan Antioksidan Antara Penderita Penyakit Jantung Koroner dan Penyakit Jantung Non Koroner Pada Pasien Rawat Jalan di RSUD Dr. Moewardi Surakarta [Skripsi]. Surakarta.

Rahajoe, L. (2007) 'Penyakit Jantung pada Perempuan', Jurnal Cardiologi Indonesia, 28(3), pp. 169-170.

Rumah Sakit Umum Zainoel Abidin (2017) Profil Rekam Medis. Banda Aceh.

Sobari, R. (2014) Hubungan Asupan Asam Lemak Jenuh dan Tak Jenuh dengan Kolesterol HDL pada Pasien Penyakit Jantung Koroner di RSUD Dr. Moewardi [Skripsi]. Surakarta.

Tuminah (2009) Prevalensi Hipertensi dan Determinannya di Indonesia. Jakarta.

Yusuf, Yusnindar and Nisma, F. (2013) Analisa Pemanis Buatan (Sakarin, Siklamat, Dan Aspartam) Secara Kromatografi Lapis 
ISSN : 2354-5852

e-ISSN : 2579-5783

Tipis Pada Jamu Gendong Kunyit Asam Di Wilayah Kelapa Dua Wetan Jakarta Timur. Perguruan Tinggi UHAMKA Jakarta.

Zuraida, R. (2015) Faktor Risiko Pola Makan Dan Hubungannya Dengan Penyakit Jantung Pada Pria Dan Wanita Dewasa Di Provinsi Lampung [Skripsi]. Universitas Lampung. 